\title{
A New Constitution for a Stable Nation: A Constitutional Study on the Long-Running Kurdish Question in Turkey
}

\author{
Hakan Kolcak ${ }^{1}$ \\ University of Essex, UK
}

\begin{abstract}
The absence of a stable nation resulted in a national problem in Turkey, the Kurdish question. Although the country has been attempting to construct a stable nation for more than a decade, it has become apparent that the construction process cannot be completed in the existence of the current Turkish Constitution. Creating a new constitution has therefore become central to the State's agenda. By employing the methods of comparative constitutional law, this article gives some suggestions for a potential new Turkish constitution that would eventually come up with a formula to form the stable nation and to help the country to resolve its long-running national problem. First, the new constitution may recognise Kurdish and its dialects as national or regional official languages. Second, it may lay a foundation for bilingual education that would enable the use of Kurdish as the language of instruction. Third, it may embrace the term 'Türkiyeli' to rule on citizenship matters. Finally, the constitution may provide constitutional protection for Kurdish linguistic, cultural and historical characteristics.
\end{abstract}

Keywords: Kurdish question, Mother tongue education, Official language, Citizenship definition, and Constitutional protection

\section{Introduction}

If a people does not feel itself a component of the juridical nation of the country identified officially in the constitution or other primary legal sources, this juridical nation cannot be acknowledged as the political nation of that country. In this circumstance, such a people may maintain its own political nation, and therefore in the country they may be different political nations while there is solely one juridical nation, causing a national problem and rendering the construction of a stable nation a difficult process, but not impossible if the country fulfils a significant number of duties (Caminal, 2011).

Turkey has been suffering from a question of stable nation for many years that has its roots in a conflict between the juridical nation of the Turks and the political nation of the Kurds. In the nationbuilding process of the Republic of Turkey, founded in 1923 in the aftermath of the collapse of the Ottoman Empire, early republican elites implemented numerous Turkification policies towards the Kurds in addition to the other non-dominant and numerically inferior communities inhabiting within the Anatolian Peninsula, the Lazes, Romas, Arabs and Circassians to name but a few only. Many groups were affected by such policies and became assimilated; in other words, they accepted the dictated identity 'Turkish nation' - which had been regarded by the republican elites as an umbrella concept covering all existing peoples within the territory of the Republic - as their primary identity. However, the Kurds, albeit all coercive assimilation policies, did not recognise the Turkish nation as an inclusive identity concept on the grounds that it had been constructed only upon ethnic Turks rather than all ethnic groups in the country. This circumstance together with the repressive policies of the military regimes and their successor governments engendered a national problem in Turkey, namely the Kurdish question.

Current politicians seek to resolve the Kurdish question since it is considered as one of the biggest obstructions to the further advancement of the country in its all aspects. I am of the belief that the identity concept 'Turkish nation' can be considered as the juridical nation of Turkey, but not its political nation, since the Kurdish community, except the assimilated Kurds, does not feel itself as an ingredient of this concept. Turkey is therefore still suffering from the absence of a stable nation, the

\footnotetext{
${ }^{1} \mathrm{PhD}$ Candidate at the Human Rights Centre

Telephone Number: +4474 40252114

E-mail: hakankolck@hotmail.com
} 
construction of which is essential for the resolution of the Kurdish issue and has already been central to the State's agenda since the early 2000s. Although Turkey has made significant strides, the main duties required for the construction process have not been fulfilled due to the present Turkish Constitution, which (a) does not allow the official use of Kurdish, (b) gives priority to ethnic Turks and defines citizenship on this ethnicity, (c) ensures constitutional protection and public funding solely for the Turkish language, history and culture, and finally (d) does not permit public schools to use Kurdish as the language of instruction.

This article is organised in the following fashion. The first section defines key concepts and explains which fundamental conditions are required to construct a stable nation. Section 2 examines the reasons why Turkey is suffering from a question of stable nation by paying a particular attention to the legal and political history of the country. Section 3 scrutinises the initial attempts made with the purpose of establishing a stable nation in Turkey. Section 4 demonstrates that the basic requirements for the formulation of the stable nation have not yet been met because of the current Turkish Constitution. Finally, the fifth section, by employing the methods of comparative constitutional law, puts forward a number of suggestions for a potential new Turkish constitution that would eventually enable the formulation of the stable nation.

\section{Conceptual Dimension}

There is a difference between juridical nation and political nation, though numerous scholars have confused the two, or have placed the former within the latter. "In the first case, there is no consultation but the registration of the national condition of the citizens and of their compulsory loyalty to the nation-state" (Caminal, 2011, p. 239). In the second, "it is the citizens who feel or do not feel linked to the political and national principles that identify the nation-state". The juridical nation does not ask the citizen; instead, it counts her and binds her to its laws and regulations. The political nation, however, does ask, since it springs from the will which is explicitly voiced by the citizenry. Even if the individual does not feel herself a member of a nation-state, she can be still part of the nation-state, meaning that "it is possible to be part of the juridical nation without feeling part of the political nation" (p. 239). This circumstance very likely causes a national problem. To clarify,

[T]here is a certain number of citizens, they may be many or relatively few, who do not feel identified with the official nation and, on the other hand, feel that they belong to another nation. This nation is their political nation, regardless of whether or not it is recognised juridically, because it is national conscience that makes the political nation (Caminal, 2011, p. 239; italics added).

Nevertheless, all national states recognised at the international level are evidently juridical nations, and "all their citizens are linked to them through the juridical code, whatever they may think or feel" (Caminal, 2011, p. 239). It is worth noting, however, that this juridical nation, despite its international recognition, is not a political nation without one of the essential sources of the legitimisation of the state, "the free expression of the will of the citizens" (p. 239), the absence of which causes a national problem and therefore renders the establishment of a stable nation a quite difficult process.

Constructing a stable nation may be nonetheless possible when the state takes at least two independent and complementary steps based upon the fact that "citizenship makes everyone equal in terms of our rights and duties, whatever our national identity or cultural condition may be" (Caminal, 2011, p. 240). First, the constitution must recognise the languages and cultures existing within the territory of the state. All the languages spoken within the borders of the state must enjoy the same rights, and "there can be no discrimination regarding duties nor in the recognition of their official nature" (p. 240). Second, the protection of such languages and cultures must be constitutionally guaranteed, and the authorities must ensure the free expression of these languages and cultures in public and in private whilst the use of such languages must also be allowed in education (p. 240).

\section{A National Question in Turkey}

The Turkish Constitution, in Article 66(1), stipulates that "[e]veryone bound to the Turkish State through the bond of citizenship is a Turk" (Law No. 2709, 1982). Accordingly, in its paragraph 4, the same provision rules that "[n]o Turk shall be deprived of citizenship, unless he/she commits an act incompatible with loyalty to the motherland." The Constitution indeed starts giving priority to Turkishness in its Preamble where it reads "no protection shall be accorded to an activity contrary to Turkish national interests, Turkish existence and the principle of its indivisibility with its State and territory, historical and moral values of Turkishness [...]" In the Preamble, it is also stated that "[this 
constitution] [h] as been entrusted by the TURKISH NATION to the democracy-loving Turkish sons' and daughters' love for the motherland and nation." The word 'Turk(s)' and the phrase 'Turkish nation' are included in Articles 5, 6(2), 7, 9, 70(1), 72, 76, 81 of the Constitution as well.

The state officials had in fact attempted to legitimise this priority to Turkishness in light of Kemalism, a state policy coming into existence upon the collapse of the Ottoman Empire's pluralist philosophy, as follows:

Kemalism had definitely chosen the territorial (French or Renan type) criterion of nation formation against the blood (German type) criterion. Atatürk's [the founder of the Republic of Turkey] most important motto: 'How happy is one who says I am Turk' instead of '... who is born a Turk' or more simply 'who is a Turk' means that Kemalism had openly opted for a subjective definition of identity and this was anyway the only feasible thing in Turkey (European Commission against Racism and Intolerance (ECRI), 1999, p. 24).

Under this theoretical assumption, the Turkish nation consists of different ethnic groups, Kurds being one of them. Being a Turk, however, does not mean membership in the largest of such groups; instead, it refers to "an all-embracive legal status, encompassing, besides other ethnic origins, those of Kurdish origin, and granting equal rights and freedoms under the guarantee of the Turkish Constitution" (ECRI, 1999, p. 29). According to the officials, moreover, Kurdish ethnic identities cannot be recognised because of three reasons: (i) historical circumstance; (ii) psychological reality; and (iii) non-existence of legal base:

Historically, the Kurds have never been recognised as an ethnic minority simply because they were Muslim, the religion of the administrators of the [Ottoman] Empire, and the impact of the Millet system dating from 1454 is still very strongly prevalent today. Psychologically, the nationalist Kurds today categorically refuse to be recognised as an ethnic minority because they consider themselves one of the founding peoples of the Turkish Republic. Finally and legally, the Lausanne Treaty (arts. 38-44), the only international instrument on this matter recognises the religious (in practice, the ethno-religious) minorities of the non-Muslims only, therefore excluding all others, the Kurds included (ECRI, 1999, p. 27).

In short, the official recognition of Kurdish ethnicity-based characteristics was considered impossible, and the identity 'Turkish nation' was regarded as an umbrella concept that covers all nations existing in Turkey, including the Kurds. I maintain that this traditional republican idea is only a theoretical argument that can be easily collapsed. The officials argued that the Kurds had not been recognised as an ethnic minority in the Ottoman history. Taking into account the concept 'ethnicity' in the classification of Ottoman nations may not be a true method to understand the Empire's recognition procedure since it did not use this concept as an element to classify its nations. Instead, in accordance with the Ottoman's Millet system, the religious criterion was taken into consideration, and as the Kurds were Muslim, they were not considered as a religious minority. Notwithstanding, this circumstance did not deprive the Kurds of constructing their own nation and of enjoying specific rights and freedoms throughout the Ottoman periods, during which they were acknowledged as one of the largest communities (cemaat) within the Empire, allowing them to enjoy judicial, administrative and fiscal autonomy over the region in which they constituted the majority, and to apply their customary laws over domestic disputes (Tas, 2013, 2014).

The officials perceived the newly formulated Turkish nation as a concept reflecting the characteristics of the Turks as well as the other elements of the Republican State. I think this is manifestly false since the nature of the Turkish nation does not mirror the features of Anatolian peoples. This can be very easily understood when looking at the early assimilation policies towards all founding peoples of the Republic, but particularly the Kurds who suffered from numerous Turkification policies during the one-party period (1923-1945), ruled by the Republican People's Party (Cumhuriyet Halk Partisi, CHP) (Demirel, 2004). As a product of the language revolution, for example, the 'Citizen, Speak Turkish!' campaign (Vatandaş, Türkçe Konuş!) was a sort of linguicidal policy ${ }^{2}$ since it condemned the use of languages other than Turkish (Zeydanlioglu, 2012). Within the scope of education, moreover, early textbooks on citizenship emphasised the slogan 'one nation, one culture, one language' (Ince, 2012). They also defined nation as a social and political community "formed by

\footnotetext{
${ }^{2}$ Linguicidal policy means a genocidal attempt made with the goal of exterminating a minority language (Zeydanlioglu, 2012, p. 103).
} 
citizens, bound by a unity of language, culture and ideal" (Ince, 2012, p. 119). On language education, such textbooks described Turkish as the most beautiful, easiest and richest language in the world while mentioning nothing about the other languages and dialects used in the Anatolian Peninsula. These textbooks also underscored the significance of "being born a Turk, living as a Turk and dying as a Turk" by saying that 'how happy is the one who says I am Turk' (Ince, 2012, p. 121).

These early policies obviously demonstrate that the republican elites did not seek to construct the national identity 'Turkish nation' upon all characteristics of Turkey's peoples, but built it solely upon the features of ethnic Turks. Together with this historical wrongdoing, the previously accepted exclusion of the Kurds from the enjoyment of minority guarantees enshrined in Articles 37-45 of the Treaty of Lausanne (1923) engendered a number of Kurdish nationalist rebellions at the very early time of the Republican State, namely the Sheikh Said Revolt, ${ }^{3}$ the Ararat Riot, ${ }^{4}$ and the Dersim Resistance. ${ }^{5}$

Turkey succeeded in quelling all these rebellious and separatist movements, but the psychological effects of such movements resulted in more restrictive state policies evolving the administrative and legal systems in a more authoritarian fashion and focussing on the security issues rather than the reconciliation of differences (Ensaroglu, 2013). Kemalist officials, on the one hand, rejected the existence of Kurdish ethnicity-based characteristics and recognised the Kurds as 'Mountain Turks' (Robins, 1996). Justice Minister Mahmut Esat Bozkurt, on the other hand, clearly stated in 1930 the status Kurds could expect in Turkey:

[We] live in a country called Turkey, the freest country in the world ... I believe that the Turk must be the only lord, the only master of this country. Those who are not of pure Turkish stock can have only one right in this country, the right to be servants and slaves (cited in Nezan, 1980, p. 65).

Under this negative psychological attitude towards the Kurds, the following restrictive policies were implemented: (1) the officially imposed duty on primary school students to take a pledge of allegiance to the State at the beginning of every school-day through uttering a radical nationalist morning oath (Andımız), including such remarks as 'I am Turk' (Türküm), 'May my existence be a gift to the Turkish existence' (Varlı̆̆ım Türk varlı̆̆ına armăgan olsun) and 'How happy is a person who calls herself/himself Turkish' (Ne mutlu Türküm diyene); (2) the filling of governmental appointments in the south-eastern regions in which the Kurds constituted the majority with the Turks; (3) the construction of boarding schools in the same regions with the purpose of educating Kurdish pupils in an environment which physically separated them from their cultural habitat and families; (4) the forced resettlement of the Kurds from the south-eastern regions to the western area where Turkish culture is dominant; (5) the prohibition of the use of any language other than Turkish in courts and in schools; (6) the ban on the use of non-Turkish surnames; (7) the prohibition of the use of the word 'Kurd(s)'; and (8) the prerequisite of belonging to a pure Turkish race for employment in the public sector and for recruitment to the army and its academies (see Kurban, 2004; Yegen, 2009).

The number of such restrictive policies dramatically increased following the military coups staged in 1960, 1971 and 1980. Just after the 1960 military intervention, the names of the Kurdish-populated villages and towns were replaced with Turkish ones. Journals publishing a number of articles on the

\footnotetext{
${ }^{3}$ This rebellion was regarded as a watershed in the development of Kurdish national identity. The members of the clandestine organisation Azadi - the main driver of the rebellion established in 1923 supported this separatist movement on the grounds of the republican elites' injustices: "political discrimination (manipulation of elections), social discrimination (ill-treated in the army, poor prospects for advancement), cultural rights (Kurdish not allowed in schools); economical exploitation (villages were plundered, no service provided for taxes)" (Strohmeier, 2003, p. 91). In addition, the leader of the rebellion Sheikh Said, at the trial of the Independence Tribunal, stated: "First I was an Arab, then a Turk and now I have become a Kurd" (Strohmeier, 2003, p.92). Strohmeier interprets this statement "as referring first to his descent from the prophet Muhammad (sayyid); second, to his loyalty to the Sultan/Caliph, [and finally] [h]e had become a Kurd by virtue of his opposition to Kemalist Turkey" (2003, p. 92).

${ }^{4}$ The leader of the Ararat Revolt, Haski Tello, one of the instigators of the Sheikh Said Revolt, described his mission as threefold: "(i) to form a center of liberation, a task he described as "making a fortress of Agri Dagh;" (ii) to proclaim the government of Kurdistan; (iii) to organize a revolutionary army divided into small units, each with a different task, unified under one leadership" (Strohmeier, 2003, p. 97).

${ }^{5}$ The legacy of the Dersim resistance was devastation and deportation and it was quashed in 1938 (Strohmeiler, 2003, p. 128).
} 
Kurdish language, folklore and literature, such as World of Peace (Barıs Dünyası), Tigris-Euphrates (Dicle-Firat), Voice (Deng), New Path (Riya Newe) and Origin of the Tigris (Dicle Kaynağl), were all banned (Gunter, 1998). In addition to the existing ban on the use of non-Turkish surnames, giving nonTurkish names to newborns was prohibited not long after the 1971 military coup (Yegen, 2009). The 1980 military administration prohibited the explanation, publication and broadcasting of thoughts in any language other than Turkish. Newspapers, books and films pertaining to the Kurdish language and culture were confiscated. As a result of the newly adopted Constitution of 1982, drafted under the aegis of military tutelage, broadcasting of Kurdish television and radio programs and teaching of the Kurdish language were prohibited (Yegen, 2009). All these oppressive policies eventually engendered the Kurdish issue and as one of its corollaries the Kurds made their major secessionist attempt with the establishment of the Kurdistan Workers' Party (Partiya Karkêran Kurdistan, PKK), which launched an independence movement through employing terrorist methods. In response to this rebellious campaign, the government announced a State of Emergency (Olăganüstü Hâl) in ten Kurdish-occupied provinces in July 1987 that bestowed governors of the provinces with broad powers, such as restricting the local press and evacuating villages on the grounds of national security.

All in all, the republican elites constructed their identity concept 'Turkish nation' with no attention to the multicultural atmosphere of Turkey. In the early nation-building process of the Republic, the main features of ethnic Turks, including their language, culture and history, were recognised as the only official characteristics of the Republican State. At the same time, Anatolian peoples, particularly the Kurds as the others became assimilated at the very beginning of the process, experienced numerous injustices that hampered and even prohibited the development of their linguistic, cultural and historical identities. This situation in company with the military regimes' oppressive administration rendered the Turkish nation an umbrella concept solely in the republican theory. In practice, the Kurds have maintained their own political nation and never acknowledged the Turkish nation as their primary identity, preventing the republican identity concept from being awarded a political status of the whole Turkey. The inclusion of this concept both in the current Turkish Constitution and in its predecessors (Constitutions of 1924 and 1961), however, has granted it a nationwide juridical status that caused a national problem: the Kurdish issue.

\section{A New Era to Form a Stable Nation in Turkey}

Turkey's capture in February 1999 of Abdullah Öcalan - the long-time leader of the PKK opened new possibilities to deal with this issue. After he was captured, Öcalan began calling for a democratic resolution to the Kurdish question. When he awaited trial in prison cell on Imrall Island, Öcalan averred that "a solution based on the unity and independence of Turkey, which would guarantee peace and real democracy [...] is also our innermost wish" (cited in Gunter, 2008, p. 63). During his trial for treason and separatism which ended with a death sentence on 29 June 1999, Öcalan also issued a significant statement that the resolution of the Kurdish issue is to implement true democracy, not to separate the Kurdish-populated regions from the unitary state (Gunter, 2008, p. 67).

After he was sentenced capital punishment, Öcalan sought to use diplomatic channels for a stay of his execution. On 18-19 September, the representatives of more than fifty states gathered in Istanbul for a summit meeting of the Organisation for Security and Co-operation in Europe (OSCE). Although the Kurdish issue was not formally broached, it was undoubtedly on the minds of many. At that time, most of European Union (EU) Member States were being ruled by leftist governments which consider the resolution of the Kurdish problem as a significant step for the democratisation of Turkey. Öcalan and his associates were all aware of this situation; therefore, they sent a quite long letter to OSCE leaders, underlining that the democratisation process cannot be completed without resolving the Kurdish question because Turkey would shape its institutions and laws in an anti-democratic manner with the goal of keeping the Kurds under control. From his prison cell, Öcalan also added the resolution of the Kurdish problem and the creation of the grounds for democracy would be a guarantee for peace in Turkey.

On 25 November 1999, however, the Turkish Court of Appeals rejected Öcalan's appeal of his death penalty. The European Court of Human Rights (ECtHR), to which Turkey belonged, then quickly issued interim measures asking for suspending the execution. While Turkey was accepted as an EU candidate member following the Helsinki Summit, European politicians considered the suspension of Öcalan's death sentence as essential for Turkey's EU future. This can be easily understood when looking at German ambassador to Turkey Hans Joachim Vergau's blunt announcement "if you executes Öcalan, you can forget Helsinki" (cited in Gunter, 2008, p. 82). The democratic resolution of the Kurdish issue was also regarded by the Union as a requirement for membership. 
Ever since Atatürk proclaimed the State's goal to be the achievement of the level of contemporary civilisation, Turkey has aimed at joining the West. This has ultimately meant membership in the Union. The achievement of this goal was however dependent on the satisfactory resolution of the Kurdish question, and this was already apparent to domestic politicians. Mesut Y1lmaz, the leader of the Motherland Party (Anavatan Partisi, ANAP), announced that "the road to the EU passes through Diyarbakır," the leading centre of the Kurdish population in Turkey (Hurriyet Daily News, 1999). He also asserted, "first of all we have to strengthen democracy, not only in its form but in its substance as well", and underlined that "my party [ANAP] does not see the broadening of rights and freedoms as a danger that threatens the state [...] that this would, on the contrary, strengthen the state apparatus"(Hurriyet Daily News, 1999). Although Prime Minister Bülent Ecevit, the leader of the Democratic Left Party (Demokratik Sol Parti, DSP), was more cautious, his foreign minister Ismail Cem supported the view that "[e]veryone should have the right to speak on television in their native language, just as I am sitting here today speaking in my own native tongue" (cited in Gunter, 2008, p. 83). President Süleyman Demirel also urged the postponement of Öcalan's execution in deference to “Turkey's higher interests" (Kinzer, 2000). Responding to European pressure, Turkish leaders decided to delay the execution until the ECtHR has ruled on Öcalan's appeal. Upon the abrogation of capital punishment, required for EU membership, Öcalan's death sentence was rescinded and then commuted to life imprisonment in 2002.

In addition to the abolishment of death sentence, since it was obliged to fulfil the Copenhagen Criteria, involving provisions on respect for and protection of national minorities, Turkey initiated a process of legislative reforms that started with the 2001 constitutional revision (Law No. 4709) and continued with a series of laws adopted in the following years, empowering Turkey to make significant strides to construct a stable nation. Once it adequately fulfilled the Copenhagen Criteria, Turkey formally began the accession negotiations with the EU in October 2005. Since then, the so-called 'Demokratik Açılım' - a government policy recognising the employment of democratic methods as the only way to resolve the Kurdish question - has dealt with the construction of the stable nation via its two programs: (i) the Kurdish Initiative, ${ }^{6}$ renamed as the National Unity and Fraternity Project upon severe criticisms of opposition parties in the parliament, expect for the pro-Kurdish Peace and Democracy Party (Barlş ve Demokrasi Partisi, BDP); and (ii) the Peace Process, which started in 2012 with the main aim of disarming the PKK.

\section{Significant Strides to Construct the Desired Stable Nation}

As explained in Section 1, a state does need to fulfil a number of main conditions to construct a stable nation. In accordance with our case study, we may categorise such conditions under five subtitles:

1. Free expression of the Kurdish language and culture in public and in private;

2. The use of Kurdish in education;

3. Constitutional recognition of Kurdish as an official language;

4. Constitutional protection for the development and maintenance of the Kurdish language, culture and history; and finally

5. Neutral citizenship definition in the Turkish Constitution.

Turkey has made a significant number of reforms in the fulfilment of the first condition since the early 2000s, authorising us to claim that Kurdish linguistic and cultural values can now be freely expressed in public and in private. Let me first note such reforms.

Kurdish broadcasting rights. The 2001 constitutional reform package laid a foundation for Kurdish broadcasting rights by removing the limitations on the usage of any language prohibited by law in the expression and dissemination of ideas in the broadcasting media (Law No. 4709, 2001, art. 9). Pursuant to this constitutional amendment, the third European harmonisation law allowed for the first time to broadcast in "different languages and dialects traditionally used by Turkish citizens in their daily lives" (Law No. 4771, 2002, art. 8). To implement, the Supreme Board of Radio and Television (Radyo ve Televizyon Üst Kurulu, RTÜK) issued an executive regulation in December 2002, which (i) established direct state control over broadcasts, (ii) introduced time limitations for broadcasts, (iii) prohibited the teaching of minority languages and children's programmes, (iv) required complete and

\footnotetext{
${ }^{6}$ The Kurdish Initiative indeed started when Prime Minister Recep Tayyip Erdogan delivered an audacious speech in the Kurdish-populated province of Diyarbakir in August 2005: "the response to the Kurds' long-running grievances is more democracy." However, the Initiative accelerated just after the Prime Minister's second speech in 2008: "democratisation is an antidote to ethnic extremism, terrorism and all types of discrimination” (Nykanen, 2013, p. 86).
} 
consecutive Turkish translation for radio programmes and Turkish subtitles for television broadcasts, (v) subjected decisions on the broadcasting language and dialect, and the profile of listeners and viewers to bureaucratic authorisation, and (vi) prohibited broadcasting in violation of the essential features of Turkey and its indivisible national and territorial integrity (see Radyo ve Televizyon Yayınlarının Dili Hakkında Yönetmelik, 2002). RTÜK issued a new regulation on 25 January 2004 in pursuit of the sixth European harmonisation law (Law No. 4928) enabling private broadcasting in Kurdish; however, almost all the restrictions introduced in the previous regulation were still in force. ${ }^{7}$ Nevertheless, after the public-funded Turkish Radio-Television Corporation (Türkiye Radyo ve Televizyon Kurumu, TRT) launched the Kurdish-language channel TRT $6,{ }^{8}$ RTÜK began abandoning its restrictive policies by adopting a new regulation in November 2009 which removed all the restrictions with the exception of the provision establishing direct state control over broadcasts. ${ }^{9}$ This abandonment process was completed in 2011 at which the parliament passed a new media law that directly allows the use of languages other than Turkish (Law No. 6112, 2011, art. 5). As a consequence of this process, the number of media service providers in Kurdish has dramatically increased and today, in addition to numerous radio stations, there are various TV channels broadcasting in different areas from music to culture, including a cartoon channel of Zarok TV, at both the nationwide level and the local level. At the moment, the Kurds can also easily watch Kurdish TV channels broadcasting from different parts of the world, mainly from the autonomous Iraqi Kurdistan, via satellite or internet. ${ }^{10}$

Kurdish names for newborns. Not long after the 1971 military intervention, giving newborns Kurdish-origin names had been prohibited through the newly adopted Civil Registry Law, under which Kurdish names had been recognised as those that have politically offensive meanings (Law No. 1587, 1972, art. 16(4)). The first positive step took place in 2000 when the Supreme Court of Appeals confirmed the freedom of individuals to "give their children any name of their choosing," including Kurdish ones (European Commission, 2000, p. 18). The sixth European harmonisation law then amended the Civil Registry Law and permitted Kurdish parents to give their children Kurdish-origin names as long as "such names comply with moral values and do not offend the public" (Law No. 4928, 2003, art. 5). To implement, however, a circular issued in September 2003 made numerous Kurdishorigin names illegal since it banned names incorporating non-Turkish letters, Q, W or X (common in Kurdish names) (ECRI, 2005). The use of Kurdish names has eventually been liberalised through the so-called '2013 Democratisation Package' which removed the ban on the use non-Turkish letters (Law No. 6529, 2014, art. 16(e)).

Kurdish names for towns and villages. Kurdish names of the south-eastern towns and villages had been changed on the grounds that these names did not have Turkish origin. The 2013 Democratisation Package has enabled the restoration of the original names of such towns and villages (Law No. 6529, 2014, art. 16(a)). The restoration process has been pursuing since March 2014. For example, the village of Vergili in the province of Batman was renamed as the village of Becirman in May 2014, and Finance Minister Mehmet Şimşek welcomed its new name following his visit to the village (Milliyet, 2014). Van Metropolitan Municipal Council, in its regular meeting in November 2014, restored the original names of 704 towns and villages (Van Büyükşehir Belediyesi Resmi Web

\footnotetext{
${ }^{7}$ Such as the prohibition of children's programmes and the teaching of minority languages, the time limitations with a revised version (for radio five hours per week, not exceeding an hour per day, for television four hours weekly, but at most forty-five minutes daily), and the requirement of Turkish translation and subtitles for broadcasts (see Türk Vatandaşlarının Günlük Yaşamlarında Geleneksel Olarak Kullandıkları Farklı Dil ve Lehçelerde Yapılacak Radyo ve Televizyon Yayınları Hakkında Yönetmelik, 2004).

${ }^{8}$ TRT 6 airs 24 hours a day and involves programs broadcast on the Kurdish cuisine, history, music, literature and culture as well as general interest programs broadcast on travel, religion, health, talk shows, debates, news and cartoons for children.

${ }^{9}$ The regulation stipulates that all radio stations and television channels intending to broadcast in languages and dialects traditionally used by Turkish citizens in their daily lives should apply to RTÜK for receiving broadcasting permission (see Türk Vatandaşlarının Günlük Yaşamlarında Geleneksel Olarak Kullandıkları Farklı Dil ve Lehçelerde Yapılacak Radyo ve Televizyon Yayınları Hakkında Yönetmelik, 2009, art. 5).

${ }^{10}$ The list of TV channels based in Turkey and other countries is available at: http://karwan.tv/ (last accessed 25 January 2015); the list of radio stations at: http://karwan.tv/radio.html (last accessed 25 January 2015).
} 
Sitesi, 2014). In December 2014, Kurdish names of four villages in Siirt were restored upon the authorisation of the Ministry of Internal Affairs. ${ }^{11}$

Kurdish in politics. The use of any language other than Turkish had been prohibited in making political propaganda through Article 58 of the Law on Basic Provisions of Elections and Electoral Rolls (Law No. 298) and Article 43 of the Law on Political Parties (Law No. 2820). In April 2010, the parliament made the first attempt to remove the prohibition by amending Article 58 of the Law No. 298 that allowed political parties and nominees to carry out Kurdish electoral campaign during the parliamentary election of 2011 (Law No. 5980, 2010, art. 7). Nevertheless, this did not entirely assure a certain independent arena for the use of Kurdish since the provision was still imposing the use of Turkish as the basis for oral and written political propaganda (see Law No. 5980, 2010, art. 7(3)). The 2013 Democratisation Package therefore further amended the same provision and stipulated that political parties and nominees could make propaganda in languages and dialects other than Turkish (Law No. 6529, 2014, art. 1). The Package also deleted the sentence in Article 43 of the Law No. 2820 that the use of any language other than Turkish in political propaganda is prohibited (Law No. 6529, 2014, art. 16(b)). Kurdish in political campaigns has thus ultimately been legally guaranteed as of March 2014 when the Package came into force.

Turkey has also made various reforms in the fulfilment of the second condition, the use of Kurdish in education; however, there is still a certain constitutional restriction on the fulfilment process. Let me first look at the positive side and mention the reforms; then turn my attention to the constitutional hindrance.

Degree programs in Kurdish. In September 2009, the Higher Education Board (Yüksek Ögretim Kurulu, YÖK) endorsed the application of Artuklu University, a public university in Mardin, to establish a 'Living Language Institute', which would provide postgraduate education in Kurdish and other Anatolian languages (European Commission, 2009). This endorsement was then authorised by a cabinet decree (no. 2009/15597) adopted on 1 December 2009 and eventually the first public institute teaching Kurdish was established. Following this university, YÖK empowered other public universities to establish departments and institutes providing both undergraduate and postgraduate education in the dialects of Kurdish, such as Bingöl University, Muş Alparslan University, Tunceli University and Dicle University. ${ }^{12}$

Kurdish courses for ordinary citizens. The first stride was made once the third European harmonisation law permitted "the opening of private courses for teaching different languages and dialects traditionally used by Turkish citizens in their daily life" (Law No. 4771, 2002, art. 11). To implement, however, the Ministry of National Education adopted an administrative regulation that rendered the provision impracticable as it introduced several restrictions on teacher qualifications. ${ }^{13}$ To open such course more easily, the seventh European harmonisation law then empowered existing private language courses to teach traditional languages and dialects used in Turkey (Law No. 4963, 2003, art. 23). The Board of Education also clarified that the trainers of Kurdish might be appointed among Turkish language and literature, primary school and foreign language teachers who know the language. Any course facing difficulty in assigning teachers of such braches was allowed to entrust graduates of other faculties or teachers of other branches. Although this had enabled the opening of seven Kurdish language courses, all were closed down as of August 2005 because they suffered from serious financial difficulties ${ }^{14}$ as well as some restrictions, relating to, in particular, the timetable, ${ }^{15}$ the attendees, ${ }^{16}$ and the curriculum. ${ }^{17}$ Kurdish for ordinary citizens has been ultimately provided upon the

\footnotetext{
${ }^{11}$ The village of Çatılı was renamed as Sinep; Çınarlısu as Hatrant; Dereyamaç as Fersaf and Oyacık as Teylan (Yeniakit, 2014).

12 A significant number of students have studied at such institutes and departments since 2012. In the 2012-2013 academic year, for instance, 250 postgraduate students studied at the Kurdish Language and Literature Department (a taught master programme) at the University of Artuklu. 50 postgraduate students also studied the same programme at Mus Alpaslan University (in the 2012-2013 season). Undergraduate students have also been pursuing their degrees at such universities since 2011 (Committee on the Elimination of Racial Discrimination (CERD), 2014).

${ }^{13}$ Teachers were required to have a graduate diploma in the language they want to teach although educational faculties in Turkey did not have any Kurdish language departments at that time. Teachers were also required to be Turkish citizens, hindering the hiring of foreign Kurdish instructors (Kurban, 2003; Zeydanlioglu, 2012).

${ }^{14}$ As they had no school status, they were not enabled to receive financial assistance from the State (Zeydanlioglu, 2012).

${ }^{15}$ Courses were allowed to last 10 weeks and no more than 18 hours per week (Zeydanlioglu, 2012).

${ }^{16}$ Only adult students were allowed to attend (European Commission, 2005).
} 
empowerment of universities to teach the language. Dicle University, for example, now provides threemonth regular courses (totally 36 hours) teaching some aspects of the Kurdish language (such as grammar, vocabulary and daily life conversations). Many participants involving academics, doctors, students, lawyers and teachers have attended such three-month courses and been awarded with a language certificate since 2011.

Elective Kurdish courses in primary schools. The 2012 legislation extending compulsory education from 8 to 12 years provides elective courses in Kurdish as well as other living languages in Turkey. A curricula issued by the Ministry of National Education in June 2013 stipulates that primary schools oblige to add a course on such languages upon the application of at least 10 pupils, indicating that the opening of such courses does not depend on the arbitrariness of schools, but on the demand of pupils. Students have started to take these elective courses, beginning from the fifth class, since 2012. Courses in three different languages, Kurdish, Circassion and Laz, are now available in the public schools. $^{18}$

Kurdish as the language of education in private schools. The 2013 Democratisation Package allowed the establishment of private schools using "any language or dialect traditionally used in Turkey [as the language of education]" (Law No. 6529, 2014, art. 11). To implement, the Ministry of National Education amended the Regulation on Private Schools in July 2014. In accordance with this regulation, the Council of Ministers is responsible for determining which languages and dialects other than Turkish could be used as the language of education, and upon its authorisation private schools would be able to hold education in different languages and dialects (Millî Eğitim Bakanlığı Özel Öğretim Kurumları Yönetmeliğinde Değişiklik Yapılmasına Dair Yönetmelik, 2014, art. 27). Not long after, the Kurdish Language Research and Development Society (Kürt Dili Araştırma ve Geliştirme Derneği) together with other non-governmental organisations made official applications for opening three schools in Diyarbakır, Şırnak and Hakkâri that would conduct education in the Kurmanji dialect of Kurdish. Although they had been prepared to open their doors on 15 September 2014, such schools were briefly sealed by local governors on the grounds that there is no constitutional base for opening them (Yoney, 2014a). The seal on Ferzad Kemanger Elementary School, a Kurdish-teaching school in Diyarbakır, was protested by citizens three times and then the Ministry of National Education removed it (Yoney, 2014b). The school is still conducting education in Kurdish under a new name that of Education Support House (Aslan and Sunar, 2014). This removal, however, does not render the opening of such schools constitutional and their future cannot be guaranteed in the existence of the constitutional restriction. The Constitution stipulates that

No language other than Turkish shall be taught as a mother tongue to Turkish citizens at any institution of education. Foreign languages to be taught in institutions of education and the rules to be followed by schools conducting education in a foreign language shall be determined by law. The provisions of international treaties are reserved (Law No. 2709, 1982, art. 42(9)).

Turkey ratified the International Convention on Civil and Political Rights (ICCPR), under which ethnic, linguistic and religious minorities "shall not be denied [...] to enjoy their own culture, to profess and practice their own religion, or to use their own language" (ICCPR, 1966, art. 27), on 23 September 2003, but made a reservation that

The Republic of Turkey reserves the right to interpret and apply the provisions of Article 27 of the International Convention on Civil and Political Rights in accordance with the related provisions and rules of the Constitution of the Republic of Turkey and the Treaty of Lausanne [...] and its Appendixes (United Nations, 1996, p. 12).

\footnotetext{
${ }^{17}$ The Ministry allowed only the teaching of the grammatical rules of the language, not any of its cultural and historical aspects (European Commission, 2005).

${ }^{18}$ In the academic years (2012-2013 and 2013-2014), "23,697 fifth graders and 19,896 sixth graders enrolled in these courses" respectively (CERD, 2014, p. 23).
} 
The Treaty of Lausanne (1923) reads that

Turkish nationals belonging to non-Moslem minorities [...] shall have an equal right to establish, manage and control at their own expense [...] any schools and other establishments for instruction and education, with the right to use their own language (art. 40).

Article 41 of the Treaty also states that

As regards public instruction, the Turkish Government will grant in those towns and districts, where a considerable proportion of non-Moslem nationals are resident, adequate facilities for ensuring that in the primary schools the instruction shall be given to the children of such Turkish nationals through the medium of their own language.

Since the Treaty of Lausanne bestows solely non-Muslim minorities with educational freedoms, and since the Constitution allows only minorities recognised in the Treaty to enjoy such freedoms, the Kurds have been automatically prevented from them, meaning that the use of Kurdish as the language of education is unconstitutional in Turkey. In addition to the non-compliance of the educational duty, the Constitution hampers the fulfilment of the last three requirements for the construction of the stable nation. Article 3 of the Constitution, under which Turkish is the only official language of the state, is an obstacle to the third condition which requires Kurdish to be recognised as an official language. In accordance with Article 134, merely Turkish linguistic, cultural and historical values enjoy constitutional protection and public funding while the fourth condition requires the same for Kurdish identities. Finally, in its several provisions, the Constitution gives priority to Turkishness and defines the concept 'citizenship' on ethnic Turks, rendering the fulfilment of the last condition, $a$ neutral constitutional citizenship definition, impossible. To put this paragraph in a more understandable way, the following basic conditions are still waiting for fulfilment:

- Kurdish as the language of education;

- $\quad$ Kurdish as an official language;

- Constitutional protection for the Kurdish language, culture and history; and

- A neutral constitutional citizenship definition.

\section{A New Constitution to Continue the Construction Process}

It is obvious that although the country's contemporary reforms have reserved the harm done by the traditional republican regime, Turkey cannot resolve its long-running Kurdish question so long as it does not create a new constitution fulfilling all the aforementioned conditions. This already became apparent to politicians and the first attempt was made in summer 2011 when the Constitutional Reconciliation Commission had been established. It was chaired by Speaker of Parliament Cemil Çiçek and comprised of three representatives of each of the four political parties in the Turkish Grand National Assembly. The Commission was given one year to formulate a new constitution and therefore began to formulate it in May 2012, following the preparatory stage during which civil society was involved in the formulation by asking its expectations, demands and opinions. Because only 48 articles had been agreed upon by the June 2013 deadline, the Commission continued to work on the constitution. Following several meetings, the Commission reached consensus only on 60 articles as of November 2013. Due to the lack of agreement upon some essential questions, the Speaker of Parliament Çiçek announced that "the Commission is not capable of drafting a new constitution from scratch" (Today's Zaman, 2013).

Creating a new constitution, nevertheless, is still deemed as an essential duty for the resolution of the Kurdish question since the constitutional restrictions are being examined during the on-going peace negotiations over the disarmament of the PKK. In an interview with the Turkish daily newspaper Milliyet, Selahattin Demirtaş, the leader of the pro-Kurdish Peoples' Democratic Party (Halkların 
Demokratik Partisi, HDP), criticised the absence of the official use of Kurdish as follows: "[t]here should be official languages other than Turkish in Turkey. Why does not the Constitution recognise Kurdish as an official language? Is it a damned language?" (Celik, 2015, p. 13). Similarly, Abdullah Öcalan called on the government to take into consideration his framework document which requires the creation of a new constitution as a crucial step to resolve the Kurdish question (Demir, 2015). Furthermore, the Letter of Intent, which was promulgated by a de facto committee, comprised of the Deputy Prime Minister, Minister of Internal Affairs and some Members of Parliaments from the HDP, underscores the significance of a new pluralist constitution in the disarmament process of the PKK, and ultimately in the resolution of the Kurdish issue (Kurdinfo, 2015). Not only pro-Kurdish politicians but also the others, especially from the ruling party Justice and Development Party (Adalet ve Kalkınma Partisi, AKP), consider a civil, liberal, democratic and pluralist constitution as essential for the resolution of the Kurdish issue and for the certain consolidation of Turkish democracy (Aydinlık, 2015). In the following subtitles, I seek to resolve how a potential new constitution can fulfil the aforementioned four requirements by taking into account both international legal instruments and the official practices of democratic countries where a progressive human rights regime is being implemented.

\subsection{Kurdish as the Language of Education}

The Kurds, the only national minority in Turkey, except the non-Muslims, ${ }^{19}$ should have already enjoyed the right to have instruction in their mother tongue in line with international legal sources that make explicit provisions for mother tongue education. The Polish Minorities Treaty, for instance, confers on racial, linguistic and religious minorities in the territory of Poland a right to establish, manage and control their own schools and other educational institutions with the right to use their mother tongue (Thornberry and Gibbons, 1997). Article 26(3) of the Universal Declaration of Human Rights (UDHR) stipulates that parents "have a prior right to choose the kind of education that shall be given to their children," enabling parents to select the language in which their children would receive education (United Nations (UN) General Assembly Resolution 3/217, 1948). Converting the premises of the UDHR into the form of binding treaty, the International Covenant on Economic, Social and Cultural Rights (ICESCR) reads that

The States Parties to the present Covenant undertake to have respect for the liberty of parents and, when applicable, legal guardians to choose for their children schools, other than those established by the public authorities, which conform to such minimum educational standards as may be laid down or approved by the State and to ensure the religious and moral education of their children in conformity with their own convictions (ICESCR, 1966, art. 13(3)).

The UN Declaration on the Rights of the Child states that "the child is entitled to receive education [...] which will promote his general culture" (UN General Assembly Resolution 1386/14, 1959, art. 29(c)). In pursuit of the Convention on the Rights of the Child (1959), "the education of the child shall be directed to the development of respect for the child parents, his or her own cultural identity, language and values" (art. 29 (c)). The UN Declaration on the Rights of Persons Belonging to Minorities (UN Declaration on Minorities) also suggests "[s]tates should take appropriate measures so that, wherever possible, persons belonging to minorities may have adequate opportunities to learn their mother tongue or to have instruction in their mother tongue" (UN General Assembly Resolution 47/135, 1992, art. 4(3)).

The 1992 European Charter for Regional or Minority Languages (European Language Charter) stipulates a more concrete and detailed provision that states should make available the whole

\footnotetext{
19 According to the most-widely agreed upon formulation of minority definition, proposed by Francesco Capotorti, only the Kurds are a national minority in Turkey as they fulfil both the objective elements (distinct history, religion, language and numbers) and subjective components (minority consciousness). The other communities in Turkey, such as the Lazs, Romas, Arabs and Circassians, neither fulfil the objective criteria (due to the individual mode of dislocation) nor the subjective ones (because of their desire to integrate into the majority culture); therefore, they are cultural minorities (immigrants and their descendants) (see Capotorti, 1976).
} 
or a substantial part of education in minority languages from pre-school level to the end of higher education within the territory where such languages are used (see art. 8).

The 1995 Framework Convention for the Protection of National Minorities (FCNM) imposes duties, for both private and public education, on the State Parties. With regards to private education, persons belonging to national minorities should enjoy the right to establish and manage their own educational and training institutions (see art. 13(1)). It is worth noting that "the exercise of this right shall not entail any financial obligation for the Parties" (FCNM, 1995, art. 13(2)). With respect to public education,

In areas inhabited by persons belonging to national minorities traditionally or in substantial numbers, if there is sufficient demand, the Parties shall endeavour to ensure, as far as possible and within the framework of their education systems, that persons belonging to those minorities have adequate opportunities for being taught the minority language or for receiving instruction in this language (FCNM, 1995, art. 14(2)).

In pursuit of these international guarantees, many democratic constitutions do not make monolingual education compulsory; ${ }^{20}$ instead, lay a foundation for bilingual (or sometimes multilingual) education that means the educational activities conducted in more than one language. For a program to be acknowledged as bilingual, both the dominant language of the society (e.g. Turkish in Turkey) and the mother tongue of at least one people living with the majority (e.g. Kurdish in Turkey) must be used as languages of education to deliver the content of the curriculum, such as Geography and Mathematics courses in the Kurdish language in Turkey. Bilingual education is therefore not only the teaching of minority languages, but it also refers to the use of those languages in the teaching of several disciplines listed in the curriculum (Kaya \& Aydin, 2013).

There are four prominent models of bilingual education, (i) transitional models, (ii) maintenance models, (iii) enrichment models and (iv) heritage models. Under the educational methods of transitional models, implemented largely in the West, as a member of a minority group, the student is generally taught both in her mother tongue and the majority language during the first two years of her education; then moves into the education in the majority language. Whilst some disciplines are taught in the mother tongue in the following academic years, the majority language is the language of education for the most part. Maintenance models employ similar methods as transitional ones, but unlike them, duration of the education in the mother tongue is longer in these models. With the aim of decreasing discrimination, developing empathy and facilitating integration among different ethnic communities, enrichment models encourage not only native speakers of the minority language but also those who do not speak that language to learn and receive education in the language. The last, heritage models seek to protect languages encountering extinction by bestowing those languages with the status of the language of instruction (Kaya \& Aydin, 2013).

Administered by provincial education policies, the United States (US) may provide an example for Turkey. Depending upon the locality of education, each US state applies specific bilingual programs; for example, in the states with a dramatic migrant population such as Illinois, New York, New Jersey and Texas, bilingual education is compulsory. Despite the existence of some historic legislation against bilingualism, the Civil Rights Act of 1964 and Bilingual Education Act constitutionally guarantee bilingual education for different ethnic minorities (Kaya \& Aydin, 2013).

The United Kingdom (UK) transited to bilingual education programs with the adoption of the Education Reform Act (1998), under which a new national curriculum was introduced. Bilingual education in the UK is currently being practiced in four regions, England, Wales, Scotland and Northern Ireland. The education is essentially aimed at the integration of immigrants in England while the goal is to preserve and advance the mother tongue in the other three regions (Kaya \& Aydin, 2013).

The Finns and Samis in Sweden had been suppressed and oppressed by Swedish central government due to numerous coercive assimilation policies; however, the oblivious and radical nationalist perspective against minority nations came to change with the labour immigrants in the 1950s. Finnish, Sami, Yiddish, Meankieli and Romanian languages were officially recognised as the languages of instruction, including kindergarten education. The right to have instruction in mother tongue is now constitutionally guaranteed which provides students with various employment advantages such areas as teaching, journalism and translation services whey they have the language proficiency essential for these jobs (Kaya \& Aydin, 2013).

\footnotetext{
${ }^{20}$ For example, Section 3 of the Swiss Constitution, Section 16 of the Finnish Constitution, Section 27 of the Spanish Constitution, Article 42 of the Irish Constitution, Article 24 of the Belgian Constitution, Article 23 of the Luxembourgian Constitution, and Article 34 of the Italian Constitution.
} 
Until the adoption of the Constitution of 1978, mother tongue education had not been allowed in Spain, but the new constitution divided Spain into autonomous regions, enabling Basque, Catalan, Occitan and Galician languages to be used as the language of education. For instance, the autonomous government of Catalonia, Generalitat de Catalunya, introduced the Language Policy Act (1998) that has rendered Catalan the education language "at all levels and types of schooling" (art. 20(1)).

The last two examples for Turkey are Switzerland and Canada. 22 out of 26 Swiss Cantons are implementing bilingual (or trilingual) education. In Canada, bilingual (or multilingual) education is very much pursuant to the official multicultural policies regarding each distinct cultural group as one cornerstone of the Canadian richness. Canada, irrespective of several ethnic communities within its boundaries, implemented constitutional arrangements merely for those native speakers of either English or French. There are however no constitutional restrictions on the use of the other languages and therefore all ethnic groups, including Aboriginal Canadians - an indigenous people comprising the First Nations, Inuit and Metis - enjoy the right to have instruction in their mother tongue (Kaya \& Aydin, 2013).

The current Article 42(9) of the Turkish Constitution not only prevents the country from constructing a stable nation, but it is also inconsistent with the international norms concerned. The new Turkish constitution may therefore not include any provisions that hinder the use of any language other than Turkish as the language of instruction, empowering the state bodies to implement a convenient model of bilingual (or multilingual) education. It is worth noting in this regard that future research projects may pay a specific attention to the determination process of the proper model and may scrutinise the above-mentioned state practices in more details.

\subsection{Kurdish as an Official Language}

In its constitutional history, Turkey did not allow the official use of any languages other than Turkish. The 1876 Ottoman Constitution (Kanun-u Esasi), in Article 18, had stipulated that "[e]ligibility to public office is conditional on a knowledge of Turkish, which is the official language of the State." This constitutional tradition was embraced by all Turkish constitutions. As a framework law, the Constitution of 1921 (Teşkilât-ı Esasiye Kanunu) did not deal with the question of the official use of languages and took into account the relevant provision of the 1876 Ottoman Constitution, indicating that it recognised solely Turkish as official language. The other historic constitutions, Constitution of 1924 (art. 2) and Constitution of 1961 (art. 3) followed the same pattern and acknowledged merely Turkish as official language. The current constitution of Turkey accepts only Turkish as official language like its predecessors, but unlike them, it makes the relevant provision (art. 3) as an irrevocable one (art. 4).

Article 3 of the Turkish Constitution deprives the Kurds who are not very good at communicating in Turkish of developing better relations with the state bodies. In accordance with Article 9 of the European Language Charter (1992), provincial judicial authorities should conduct civil and criminal proceedings in minority languages at the request of the parties. These authorities should allow an accused or a litigant to use her/his minority language; should not consider evidence and request, whether oral or written, inadmissible merely since they are formulated in a minority language; and finally such authorities should produce, on request, documents relating to legal proceedings in minority languages. The Charter, in Article 10, also reads that provincial administrative bodies may allow the use of minority languages within the framework of the local authority; may allow users of minority languages to submit written or oral applications and receive a reply in such languages; may publish their official documents in minority languages; may use minority languages in regular debates in their assemblies; and finally they may use minority languages in the provision of public services.

The FCNM (1995) imposes similar duties on the state signatories. Article 10(2) FCNM reads, for instance, that

In areas inhabited by persons belonging to national minorities traditionally or in substantial numbers, if those minorities so request and where such a request corresponds to a real need, the state signatories should endeavour to ensure the conditions which would make possible the official use of minority languages in the administrative authorities.

\section{Article 10(3) FCNM also states}

The Parties undertake to guarantee the right of every person belonging to a national minority to be informed promptly, in a language which he or she understands, of the reasons for his or 
her arrest, and of the nature and cause of any accusation against him or her, and to defend himself or herself in this language, if necessary with the free assistance of an interpreter.

In light of these provisions, several democratic states empower their peoples to use their own language officially. In these countries, there are two main alternatives at the constitutional level, namely direct recognition and indirect recognition.

\subsubsection{Direct Recognition}

The constitution may declare more than one official language. There are a significant number of countries which directly recognise different languages spoken within their territories as national or regional language at the constitutional level. The Constitution of Switzerland (1999) recognises French, Italian, German and Romansh as national official languages (art. 4). Switzerland is a confederation comprised of the Cantons (see art. 1). Article 70(2) of the Constitution authorises all cantons to decide on their official languages whilst Article 70(1) acknowledges the four languages as the official languages of the Confederation.

The Constitution of Finland (1999), in Section 17(1), recognises Finnish and Swedish as national languages. In accordance with the Language Act (2003), adopted with the aim of implementing Section 17(2) of the Constitution, every Finnish citizen enjoys the right to use his or her own language, either Finnish or Swedish, before the courts and regional, municipal and state authorities. The Language Act also guarantees the right of every Finnish citizen to receive official documents in that language (see Ihalainen \& Saarinen, 2014). In light of the Sami Language Act (2003), adopted with the goal of implementing Section 17(3) of the Constitution, the Sami language has a legal status as well as the other two. The Act, on the one hand, secures Sami linguistic rights such as the rights of Sami to use their own language before the courts and other public authorities. It, on the other hand, imposes a duty on the public authorities to enforce and promote such linguistic rights. Finally, Section 51(1-2) of the Finnish Constitution allows the use of the two national languages in parliamentary work as well.

Pursuant to the Constitution of Spain (1978), Castilian is the official language of the State, and the other Spanish languages may be used officially in "the respective Self-governing Communities in accordance with their Statutes" (art. 3). In this regard, Galician, Catalan and Basque are regional official languages and they are used in the regions shown below.

Figure 1. Official Language Areas in Spain (retrieved from Planetware, 2015).
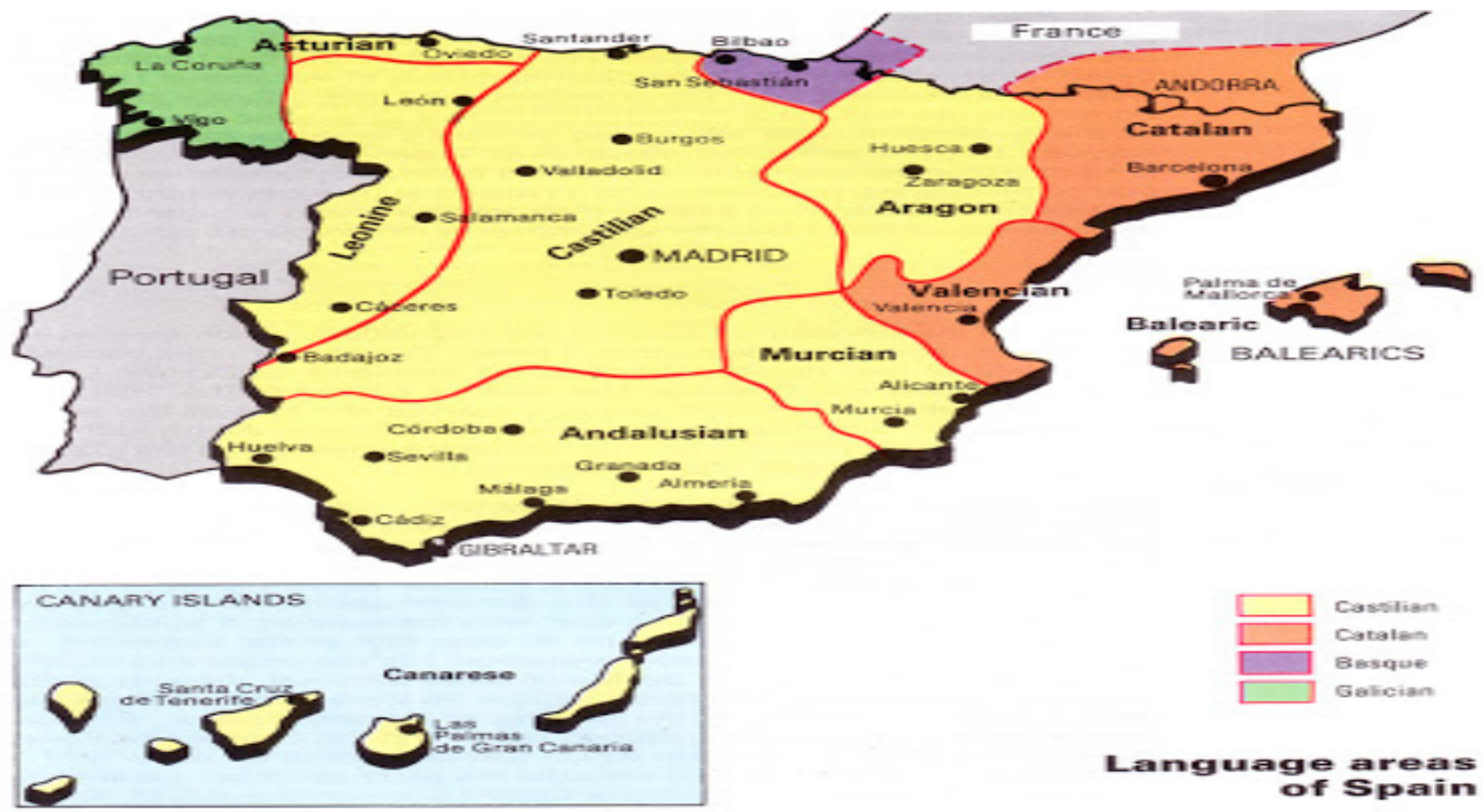
The Canadian Constitutional Act of 1982 acknowledges English and French as the official languages of the state (art. 16). The use of the two languages in "all institution of the Parliament and government of Canada" is also ensured in Article 16(1) of the Constitutional Act. As a final example for the mechanism of direct recognition, the Constitution of Ireland (1937) recognises both Irish and English as the official languages of the state (see art. 8).

\subsubsection{Indirect Recognition}

The constitution may not give any prejudices to a language and may impose a duty on the law to rule on this matter. A law then deals with the recognition of official languages as embraced by the Belgian and Luxembourgian legal systems. The Constitution of Belgium (1831) stipulates that "[t]he use of languages spoken in Belgium is free; only the law can rule on this matter, and only for acts of the public authorities and for legal matters" (art. 30). Belgium was divided into four linguistic areas by law in 1962 and this division was incorporated in the Constitution in 1970 (art. 4). At the moment, each linguistic region has its own official language(s): Flanders Region uses Flemish, a dialect of Dutch, as its official language; Wallonia uses French; a small part of Walloon Region uses German; and finally the Brussels region is officially bilingual (Dutch-French) (see Peeters 2007; Iacovino and Erk, 2012).

Figure 2. Linguistic Areas in Belgium (retrieved from Verjans, 2014).
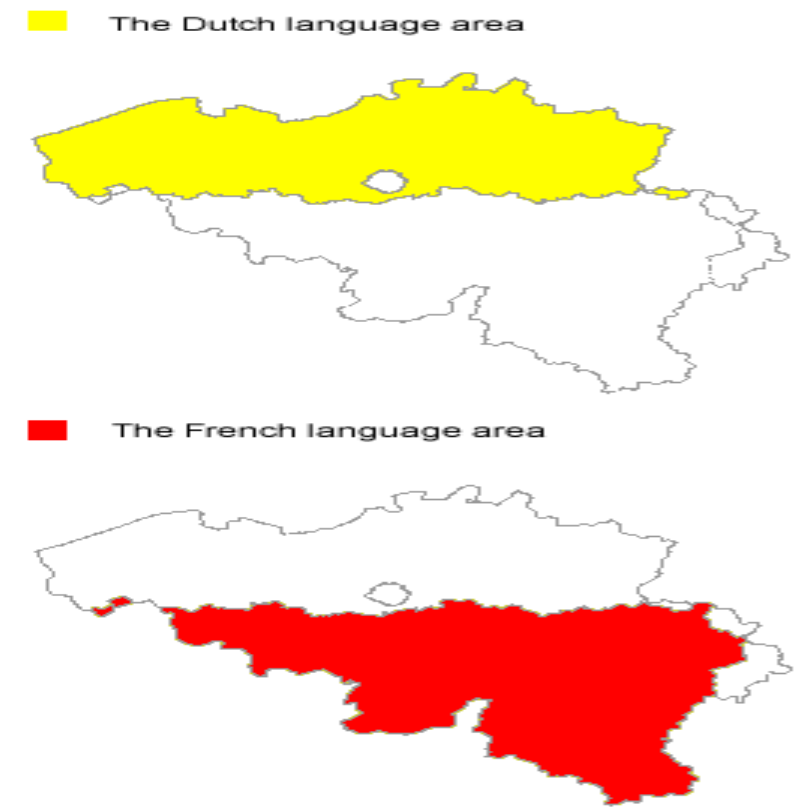

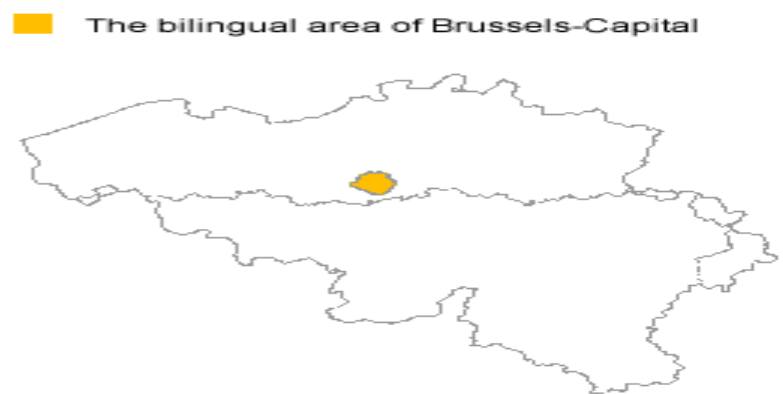

Dhe German language area

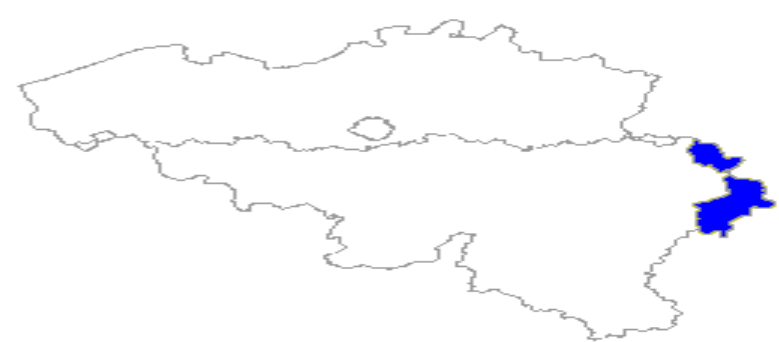

The Constitution of Luxembourg (1868) embraces the mechanism of indirect recognition like its Belgian counterpart. In Article 29, the Luxembourgian Constitution reads that "the law regulates the use of languages in administrative and judicial matters." The language law was ratified on 24 February 1984, formally enshrining Luxembourgish as the national language of the state (art. 1). According to the same law, French was officially recognised as the language of legislation (art. 2) and all administrative matters were to be carried out in Luxembourgish, French and German (art. 3). The three languages were ultimately awarded an official status in Luxembourg upon the ratification of the language law (Redinger, 2010).

In light of these constitutional practices, the new Turkish constitution may declare more than one official language (direct recognition); or it may not give any prejudices to a language and may impose a duty on the law to rule on this matter (indirect recognition). Both mechanisms, I think, are welcomed in Turkey. Within the context of the first one, the new constitution may declare not only Turkish but also the other traditional languages and dialects as the national languages of the state. Alternatively, it may still acknowledge Turkish as the only national language, but with empowering the provincial state bodies, including administrative and judicial authorities, to use the traditional languages and dialects officially, rendering Kurdish and its dialects regional official languages. Within the context of the second mechanism, the new constitution may impose a duty on the law to rule on this matter, and then a law may deal with the official use of languages. A similar scenario can be imagined: 
the law may recognise all the traditional languages and dialects as national official languages; or, it may acknowledge only Turkish as national language while awarding the others a regional official status.

\subsection{Constitutional Protection for the Kurdish Language, History and Culture}

A duty of safeguarding minority culture, history and language is already appeared in a significant number of international legal documents. The UN Declaration on Minorities (1992) states, for example, that "[s]tates should, where appropriate, take measures in the field of education, in order to encourage knowledge of the history, traditions, language and culture of the minorities existing within their territory" (UN General Assembly Resolution 47/135, 1992, art. 4(4)). The European Language Charter (1992) rules that the State Parties undertake to make arrangements to guarantee the teaching of the history and the culture which is reflected by the minority or regional language $(\operatorname{art} .8(1)(\mathrm{g}))$. The FCNM (1995) stipulates that the State Parties should maintain and develop minority cultures via promoting the conditions necessary for members of national minorities, and secure the main elements of minority identity, namely traditions, cultural heritage, language and religion (art. 5(1)).

As a drawback on the construction of the stable nation, Article 134 of the Turkish Constitution provides public funding and constitutional protection for the maintenance and promotion of the Turkish language, history and culture while mentioning nothing about the other Anatolian values. In democratic states, however, the constitution does not grant a privilege to a specific ethnic group; rather, in light of the principle of equality, the constitution mainly seeks to protect and advance the characteristics of all communities within the state. For example, the Spanish Constitution, in its Preamble, secures "all Spaniards and peoples of Spain in the exercise of human rights, of their culture and traditions, languages and institutions." Similarly, the Constitution of Italia (1948) rules that "the Republic promotes the development of culture and of scientific and technical research" (art. 9(1)), permitting the German-speaking nation in South Tyrol to enjoy the same privilege as ethnic Italians.

The principle of equality is enshrined in other democratic and pluralistic constitutions as well. According to the Finnish Constitution, "the Public Authorities shall provide for the cultural and societal needs of the Finnish-speaking and Swedish-speaking population of the country on an equal basis" (Section 17(2)). Moreover, the Sami, the Roma and other groups enjoy the right to preserve and advance their own language and culture in accordance with Section 17(3) of the Constitution. Although the Swiss Constitution acknowledges cultural matters as a cantonal responsibility (art. 69(1)), it encourages the Confederation to support cultural activities of the Cantons (art. 69(2)).

By resting upon the principle of equality as embraced by the above-mentioned constitutional practices, the new Turkish constitution may protect and provide the required authorisation for the development of not only Turkish identities, but also the other Anatolian cultural, linguistic and historical characteristics, including Kurdish ones.

\subsection{A Neutral Constitutional Citizenship Definition}

The Turkish Constitution defines the concept 'citizenship' solely upon one ethnicity while the country is home to different ethnic groups. In Article 66(1), it stipulates that "[e]veryone bound to the Turkish State through the bond of citizenship is a Turk" (Law No. 2709, 1982; italics added). This definition was indeed examined by the Constitutional Reconciliation Commission when it had attempted at creating a new constitution from 2011 to 2013. It was generally argued that the Constitution should not have given priority to ethnic Turks and it should have embraced the principle of neutrality on the issue of citizenship definition. As a corollary of this argument, a new citizenship concept had been introduced: 'Türkiyeli' which means a person living in the territory of Turkey (Oran, 2011).

Constitutional practices in democratic states, except mononational countries, generally support the argument above. We do not therefore need to reinvent the wheel. In multinational countries, where a progressive human rights regime is being implemented, the constitution does not give priority to an ethnic community and take into account the principle of neutrality on citizenship matters, e.g. the Spanish and Italian Constitutions, which do not define citizenship and use more general terms 'all citizens' or 'every citizen' when rights and duties are given. The Finnish Constitution does not define citizenship like its Spanish and Italian counterparts, but uses a more concrete notion: Finnish citizen(s). This notion is however as neutral as the terms 'every' or 'all'. The Constitution imposes a duty on the law to rule on citizenship matters (see section 5(1)); accordingly, the Nationality Act (2003) defines citizenship as "a legislative bond between an individual and the State determining the individual's status in the State as well as the basic rights and duties existing between the individual and the State" (section 2(1)(1)). 
One may investigate the neutrality of the concept 'Türkiyeli'. It is, I think, a citizenship notion representing not only ethnic Turks, but also the other founding peoples of Turkey, the Kurds, Lazes, Yezidis, Armenians, Greeks, Roma, Circassians to name just a few, as built upon the territorial criterion of nation formation rather than the blood criterion. A territory-based citizenship concept is also enshrined in the Constitution of Switzerland that defines Swiss citizen as "[a]ny person who is a citizen of a commune and of the Canton to which that commune belongs" (art. 37(1)). Hence, the new Turkish constitution may embrace the term 'Türkiyeli', a citizenship definition constructed upon the principle of neutrality by taking into consideration the territorial criterion of nation formation, and it may read that Everyone bound the Republic of Turkey through the bond of citizenship is a Türkiyeli.

\section{Conclusion}

The non-existence of a stable nation caused a national problem in Turkey, the Kurdish question. Formulating a stable nation however became central to the State's agenda in the early 2000 s. The country made a significant number of reforms permitting the free expression of the Kurdish language and culture in public and in private (such as Kurdish broadcasting rights, Kurdish names for newborns, Kurdish names for towns and villages, and the use of Kurdish in politics).

We also witnessed some important developments in the area of education, e.g. degree programs in Kurdish, Kurdish language courses for ordinary citizens, elective Kurdish language courses in primary schools, and the use of Kurdish as the language of education in private schools. Although these developments have created a more democratic educational arena for Anatolian peoples, they are not enough to convince us to assert that Turkey has fulfilled all the educational requirements for the construction of the stable nation. First, only private schools, not public ones, have been allowed to conduct education in Kurdish; and second, there are no constitutional bases even for the opening of such private schools. The Turkish Constitution is also a hindrance to the fulfilment of the other main requirements for the stable nation: it recognises only Turkish as the language of the state; provides constitutional protection only for the Turkish language, culture and history; and finally gives priority to ethnic Turks and defines citizenship solely on this ethnicity.

In the existence of these constitutional restrictions, it became obvious that the stable nation could not be formed in Turkey. The parliament therefore made an attempt to create a new constitution in 2011; however, it failed owing to the lack of consensus upon some essential questions. Creating a new constitution is nevertheless central to the State's agenda and many politicians have underscored its priceless impact on the establishment of the stable nation and ultimately on the resolution of the Kurdish question.

By employing the methods of comparative constitutional law, this article gives the following suggestions for a potential new Turkish constitution that is aimed at resolving the Kurdish question. The new constitution may not include any provisions that make monolingual education compulsory, empowering the state organs to implement a model of bilingual (or multilingual) education. There are four prominent models of bilingual education, transitional, maintenance, enrichment and heritage. Further research projects, by paying a particular attention to the state practices scrutinised in this article, may attempt to answer which model is the most appropriate one for Turkey.

Second, the new constitution may take into account two mechanisms on the issue of the official use of Kurdish, namely direct recognition and indirect recognition, both of which, I think, are welcomed in Turkey. Within the scope of the first mechanism, the new constitution may declare both Turkish and the other traditional languages and dialects as the national languages of the state; alternatively, it may still acknowledge Turkish as the only national language, but with authorising the provincial state bodies to use the traditional languages and dialects officially, rendering Kurdish and its dialects regional official languages. A parallel scenario can be envisaged within the scope of the second mechanism: A law implementing a constitutional provision may recognise all the traditional languages and dialects as national official ones; or, it may acknowledge only Turkish as national language whilst awarding the others a regional official status.

Third, the new constitution, by resting upon the principle of equality, may protect and provide the required empowerment for the advancement of not only Turkish characteristics, but also the other Anatolian cultural, linguistic and historical identities, involving Kurdish ones. Last but not least, the new constitution may embrace the term 'Türkiyeli', a citizenship concept built upon the principle of neutrality, on the issue of citizenship definition. It may thus read that everyone bound the Republic of Turkey through the bond of citizenship is a Türkiyeli; accordingly, the term 'Türkiyeli(s)' may be used when the constitution vests rights and duties in the citizen(s). As a consequence, I believe the new constitution considering these recommendations may make a significant stride to construct the stable nation that would ultimately have a crucial role in the resolution of the Kurdish issue. 


\section{References}

Aslan, F., \& Sunar, S. (2014, November 7). Kürtçe okul yeniden açıldı. Hürriyet. Retrieved from http://www.hurriyet.com.tr/gundem/27528410.asp

Büyükşehir Belediye Meclisi 704 köy ve mahallenin isimleri geri iade etti. (2014, November 9). Van Büyükşehir Belediyesi Resmi Web Sitesi. Retrieved from http://www.van.bel.tr/tr/i/B\%C3\%BCy\%C3\%BCk\%C5\%9Fehir_Belediye_ Meclisi_704_k\%C3\%B6y_ve_mahallenin_isimleri_geri_iade_etti

Capotorti, F. (1976). Study on the rights of persons belonging to ethnic, religious and linguistic minorities. New York, NY: Official Publication of the United Nations.

Caminal, M. (2011). Democracy, federalism and plurinational states. In F. Requejo and M. Caminal (Eds.), Political liberalism and plurinational democracies (pp. 226-251). New York, NY: Routledge.

Canadian Constitutional Act. (1982). Retrieved from http://lawslois.justice.gc.ca/-eng/const/ Catalan Language Policy Act. (1998). Spain.

Celik, H. (2015, January 8 ). Hakan Celik ile bir Ankara muhabbeti. Milliyet, p.13. Committee on the Elimination of Racial Discrimination (CERD). (2014). Combined fourth to sixth periodic reports of states parties on Turkey. Retrieved from http://www.ecoi.net/file_upload/1930_1406711465_g1442643-1.pdf

Constitution of Belgium. (1831). Retrieved from http://www.constcourt.be/en/basic_text/belgian_constitution.pdf

Constitution of Ireland. (1937). Retrieved from http://www.irishstatutebook.ie/en-/constitution/

Constitution of Italy. (1948). Retrieved from https://www.senato.it/documenti/repository/istituzione/costituzione_inglese.pdf

Constitution of Finland. (1999). Retrieved from http://www.finlex.fi/en/laki/kaannokset/1999/en19990731.pdf

Constitution of Luxembourg. (1868). Retrieved from https://www.constituteproject.org/constitution/Luxembourg_2009.pdf

Constitution of Spain. (1978). Retrieved from http://www.congreso.es/portal/page/portal/Congreso/Congreso/Hist_Normas/Norm/const_espa_texto_ingles_0.pdf

Constitution of Switzerland. (1999). Retrieved from https:/www.admin.ch/opc/en/classifiedcompilation/19995395/201405180000/101.pdf

Convention on the Rights of Child. Nov. 20, 1989, 1577 U.N.T.S. 3.

Davutoğlu ve Kılıçdaroğlu TOBB'da konuştu: Ortak vaatleri yeni anayasa!. (2015, May 3). Aydınlık. Retrieved from http://www.aydinlikgazete.com/politika/davutoglu-ve-kilicdaroglutobbda-konustu-ortak-vaatleri-yeni-anayasa- h69062.html

Demir, E. Y. (2015, February 19). Öcalan'ın sunduğu 10 maddelik metnin detayları konuşuluyor. Milliyet. Retrieved from http:/www.haberturk.com/gundem/haber/1044734-ocalaninsundugu-10maddelik-metnin-detaylari- konusuluyor

Demirel, T. (2004). Soldiers and civilians: The dilemma of Turkish democracy. The Middle East Journal, 40(1), 127-150.

Education Reform Act. (1998). UK.

Ensaroglu, Y. (2013). Turkey's Kurdish question and the peace process. Insight Turkey, 15(2), 7-17.

European Commission. (2000). Turkey 2000 regular report. Retrieved from http://ec.europa.eu/enlargement/archives/pdf/key_documents/2000/tu_en.pdf

(2005). Turkey 2005 progress report. Retrieved from http://ec.europa.eu/enlargement/archives/pdf/key_documents/2005/package/sec_1426_final_progress_report_tr_en.pdf

(2009). Turkey 2009 progress report. Retrieved from http://ec.europa.eu/enlargement/pdf/key_documents/2009/tr_rapport_2009_en.pdf

European Commission against Racism and Intolerance (ECRI). (1999). ECRI's country-by-country approach: Report on Turkey. Retrieved from http://hudoc.ecri.coe.int/XMLEcri/ENGLISH/Cycle_01/01_CbC_eng/01-cbc-turkey-eng.pdf

(2005). European Commission against Racism and Intōerance's third report on Turkey. Retrieved from http://hudoc.ecri.coe.int/XMLEcri/ENGLISH/Cycle_03/03_CbCeng/TUR-CbC-III-2005-5-ENG.pdf

European Charter for Regional or Minority Languages. Nov. 4, 1992, ETS 148. Framework Convention for the Protection of National Minorities (FCNM), Feb 1, 1995, ETS 157.

Gunter, M. M. (1998). The Kurdish problem in Turkey. (1998) The Middle East Journal, 42(3), 389406. 
(2008). The Kurds ascending: The evolving solution to the Kurdish problem in Iraq and Turkey. New York, NY: Palgrave Macmillan.

Hopes fade for new charter as commission dissolved. (2013, November 19). Today's Zaman. Retrieved from http://www.todayszaman.com/news-331799- hopes-fade-for-new-charter-ascommission-dissolved.html

Hükümet ve HDP ilk kez ortak açıklama yaptı; 'Silah bırakma' için Öcalan'ın kongre çağrısı duyuruldu!. (2015, February 28). Kurdinfo. Retrieved from http://www.kurdinfo.com/nuce_bixwine.asp?id=6563

Iacovino, R. \& Erk, J. (2012). The constitutional foundations of multination federalism: Canada and Belgium. In Seymour, M. \& Gagnon A. G. (Eds), Multinational federalism: Problems and prospects (pp. 205-230). New York, NY: Palgrave Macmillan.

Ihalainen, P., \& Saarinen, T. (2014). Constructing 'language' in language policy discourse: Finnish and Swedish legislative process in the 2000s. In Halonen, M., Ihalainen, P., \& Saarinen, T. (Eds.), Language policies in Finland and Sweden: Interdisciplinary and multi-sited comparison (pp. 29-56). Bristol, England: Multilingual Matters.

Ince, B. (2012). Citizenship education in Turkey: Inclusive or exclusive. Oxford Review of Education, 38(2), 115-131.

International Covenant on Civil and Political Rights (ICCPR). (1966, December 16) 999 U.N.T.S. 171. International Covenant on Economic, Social and Cultural Rights (ICESCR), (1966, December 16). 993 U.N.T.S. 3.

Kaya, I. \& Aydin, H. (2013). The question of mother tongue education in Turkey: challenges, experiences, and model recommendations for bilingual education. UKAM. Retrieved from http://www.ukam.org/e/pdf/UKAM-Rapor1-ENG(2).pdf

Kinzer, S. (2000, January 13). Turkey delays the execution of rebel Kurd. New York Times. Retrieved from http://www.nytimes.com/2000/01/13/world/turkey-delays-the-execution- ofrebel-kurd.html

Kurban, D. (2003). Confronting equality: The need for constitutional protection of minorities on Turkey's path to the European Union. Columbia Human Rights Law Review, 35(1), 151-214.

(2004). Unravelling a trade-off: Reconciling minority rights and full citizenship in Turkey. European Yearbook of Minority Issues, 4. 341-372.

Kürtçe tabelayı bakan astı. (2014). 25 May, Milliyet. Retrieved from http://www.milliyet.com.tr/kurtce-tabelayi-bakan-asti-gundem-1887614/Language Act. (2003). Finland.

Law No. 1587, Nüfus Kanunu 1972 (Turkey).

Law No. 2709, Türkiye Cumhuriyeti Anayasası 1982 (Turkey).

Law No. 4709, Türkiye Cumhuriyeti Anayasasının Bazı Maddelerinin Değiştirilmesi Hakkında Kanun 2001 (Turkey).

Law No. 4771, Çeşitli Kanunlarda Değişiklik Yapılmasına İlişkin Kanun 2002 (Turkey).

Law No. 4928, Çeşitli Kanunlarda Değişiklik Yapılmasına İlişkin Kanun 2003 (Turkey).

Law No. 4963, Çeşitli Kanunlarda Değişiklik Yapılmasına İlişkin Kanun 2003 (Turkey).

Law No. 5980, Seçimlerin Temel Hükümleri ve Seçmen Kütükleri Hakkında Kanun ile Milletvekili Seçimi Kanununda Değişiklik Yapılmasına Dair Kanun 2010 (Turkey).

Law No. 6112, Radyo ve Televizyonların Kuruluş ve Yayın Hizmetleri Hakkında Kanun 2011 (Turkey).

Law No. 6529, Temel Hak ve Hürriyetlerin Geliştirilmesi Amacıyla Çeşitli Kanunlarda Değişiklik Yapılmasına Dair Kanun 2014 (Turkey).

Millı Ĕ̆itim Bakanlı̆̆ı Özel Öğretim Kurumları Yönetmeliğinde Değişiklik Yapılmasına Dair Yönetmelik. (2014). Turkey.

Nationality Act. (2003). Finland.

Nezan, K. (1980). The Kurds under the Ottoman Empire. In Gerard Chaliand (Ed.), People without a country: The Kurds and Kurdistan (pp. 47-106). London, England: Zed Press.

Nykanen, J. (2013). Identity, narrative and frames: Assessing Turkey's Kurdish initiatives. Insight Turkey, 15(2), 85-101.

Oran, B. (2011, January 11). The issue of ‘Turkish' and 'Türkiyeli' (Turkey national; from Turkey). Today's Zaman. Retrieved from http:/www.todayszaman.com/news-232143-theissue-of $\%$ E2\%80\%9C-turkish $\%$ E2\%80\%9D-and- $\%$ E2\%80\%9Cturkiyeli $\%$ E2\%80\%9Dturkey-national-from-turkey.html

Peeters, P. (2007). Reflections on the Belgian federal state. In Burgess, M. \& Pinder, J. (Eds.), Multinational federations (pp. 31-49). New York, NY: Routledge. 
Planetware. (2015). Language areas of Spain map [Map]. Retrieved from http://www.planetware.com/map/spain-language-areas-of-spain-map-e-e5.htm Radyo ve Televizyon Yayınlarının Dili Hakkında Yönetmelik. (2002). Turkey.

Redinger, D. (2010). Language planning and policy on linguistic boundaries: the case of Luxembourgish. In Millar, M. R. (Ed.), Marginal dialects: Scotland, Ireland and beyond (pp. 90-106). Aberdeen, Scotland: Forum for Research on the Languages of Scotland and Ireland.

Robins, P. (1996). The overlord state: Turkish policy and the Kurdish issue. International Affairs, 69(4), 657-671.

Sami Language Act. (2003). Finland.

Siirt'te köy isimleri değişti. (2014, December 24). Yeniakit. Retrieved from http://www.yeniakit.com.tr/haber/siirtte-koy-isimleri-degisti42452.html

Strohmeier, M. (2003). Crucial images in the presentation of a Kurdish national identity: Heroes and patriots, traitors and foes. Leiden, the Netherlands: Brill.

Tas, L. (2013). One state, plural options: Kurds in the UK. The Journal of Legal Pluralism and Unofficial Law, 45(2), 167-189.

(2014). The myth of the Ottoman millet system: Its treatment of Kurds and a discussion of territorial and non-territorial autonomy. International Journal on Minority and Group Rights, 21(4), 497-526.

Treaty of Lausanne, Principal Allied and Associated Powers and Turkey, July 24, 1923, 28 L.N.T.S. 11.

Thornberry, P. \& Gibbons, D. (1997). Education and minority rights: A short survey of international standards. International Journal on Minority and Group Rights, 4(2), p. 115-152.

Türk Vatandaşlarının Günlük Yaşamlarında Geleneksel Olarak Kullandıkları Farklı Dil ve Lehçelerde Yapılacak Radyo ve Televizyon Yayınları Hakkında Yönetmelik 2004 (Turkey).

Türk Vatandaşlarının Günlük Yaşamlarında Geleneksel Olarak Kullandıkları Farklı Dil ve Lehçelerde Yapılacak Radyo ve Televizyon Yayınları Hakkında Yönetmelik 2009 (Turkey).

United Nations. (1996). International covenant on civil and political Rights. Retrieved from https://reaties.un.org/doc/Publication/MTDSG/Volume\%20I/Chapter\%20IV/iv-4.en.pdf

UN General Assembly Resolution 3/217, Universal Declaration of Human Rights, A/RES/3/217 (10 December 1948).

UN General Assembly Resolution 1386/14, Declaration of the Rights of the Child, A/RES/1386/14 (20 November 1959).

UN General Assembly Resolution 47/135, Declaration on the Rights of Persons Belonging to National or Ethnic, Religious and Linguistic Minorities, A/RES/47/135 (18 December 1992).

Verjans, S. (2014, November 12). Belgium. POERUP. Retrieved from http://poerup.referata.com/wiki/Belgium

Yegen, M. (2009). "Prospective Turks" or "pseudo Citizens": Kurds in Turkey. The Middle East Journal, 63(4), 597-615.

Yilmaz: Road to EU passes through Diyarbakir. (1999, December 17). Hurriyet Daily News. Retrieved from http://www.hurriyetdailynews.com/default.aspx?pa-geid=438\&n=yilmaz-road-to-eupasses-through-diyarbakir-1999-12-17

Yoney, Y. (2014a, September). Kurdi-Der awating response for Kurdish-teaching schools. Bianet. Retrieved from http:/www.bianet.org/english/education/158726-kurdi-der-awaitingresponse-for-kurdish-teaching-schools

(2014b, November 6). Kurdish-teaching school unsealed by officials. Bianet. Retrieved from http://www.bia-net.org/english/world/159756-kurdish-teaching-school-unsealed-by-officials

Zeydanlioglu, W. (2012). Turkey's Kurdish language policy. International Journal of the Sociology of the Language, 2012(217), 99-125. 